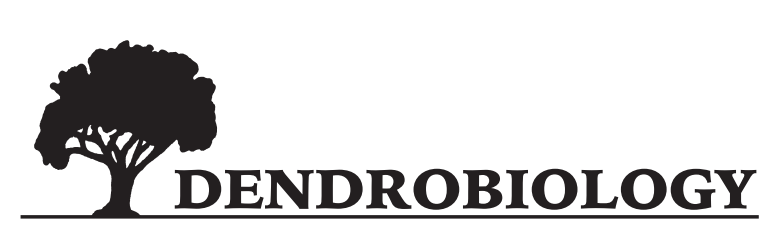

2014, vol. 71, 59-71

http://dx.doi.org/10.12657/denbio.071.006

\author{
Lukáš Bílek, Jiři Remeš, Vilém Podrázský, \\ Dusan Rozenbergar, Jurij Diaci, Daniel Zahradník
}

\title{
Gap regeneration in near-natural European beech forest stands in Central Bohemia - the role of heterogeneity and micro-habitat factors
}

Received: 06 June 2012; Accepted 19 June 2013

\begin{abstract}
Gap regeneration in a European beech (Fagus sylvatica L.) forest reserve was analyzed in relation to within-gap resource heterogeneity and ground vegetation competition. The study was carried out in two one-hectare permanent research plots (PRP) which included five smaller research plots (RP) encompassing two large gaps (500-700 $\mathrm{m}^{2}$ ), two small gaps (300-400 $\left.\mathrm{m}^{2}\right)$, and location under canopy. The coverage of woody regeneration, ground vegetation, dead wood, seedling density in eight height classes, characteristics of dominant trees of the beech regeneration, and the total thickness of holorganic horizons were measured. Soil moisture and light conditions were also assessed in selected sample plots. The relative direct and diffuse light was estimated by hemispherical photography. Small gaps showed both the highest cover of tree regeneration and the highest density of individuals per hectare. Slightly less regeneration was recorded in large gaps, while under closed canopy, regeneration densities were 5-10 times lower than in small gaps. Beech regeneration cover and the size (diameter and height) of dominant beech seedlings were positively related to relative diffuse light and negatively related to ground vegetation cover. The latter was positively related to diffuse light and soil moisture content. A pronounced statistically significant contrast in the cover and size of beech regeneration in relation to micro-site conditions (diffuse light, cover of graminoids) was only confirmed between sample plots located below canopy cover and those within gaps. Graminoids, in particular Calamagrostis epigejos L., occurred mainly in the large gap centre and along the southernmost edge of the large gap, increasing competition for resources here. The cumulative cover of ground vegetation and regeneration was relatively low (9-56\%) compared with more mesic natural beech forests. The indicated negative influence of direct light at the northern gap edge suggests that extension of gaps on comparable sites in managed forest should not proceed in this direction.
\end{abstract}

Additional key words: Fagus sylvatica, natural regeneration, ground vegetation, resource heterogeneity, competition

Addresses: L. Bílek, J. Remeš, V. Podrázský, D. Zahradník, Czech University of Life Sciences Prague, Faculty of Forestry and Wood Sciences, Kamýcká 129, 16521 Prague, Czech Republic, e-mail: bilek@fld.czu.cz

D. Rozenbergar, J. Diaci, University of Ljubljana, Biotechnical Faculty, Department of Forestry and Renewable Forest Resources, Vecna pot 83, 1000 Ljubljana, Slovenia 


\section{Introduction}

Today, forests in nature reserves, national parks, and protected landscape areas comprise approximately $25 \%$ of the forest cover in the Czech Republic. In these areas, ecological, protective, and social functions receive more emphasis than timber production. Nature reserves and other protected areas provide an important reference for managed production forests and a basis for evaluating new methods for near-natural silviculture based on principles of sustainability (Průša 1985). Since the 1970s, the remnants of natural (beech) forests in nature reserves in the Czech Republic have been subjected to increasing research and monitoring efforts in order to understand their structure and natural dynamics (Průša 1985, Vrška et al. 2001). However, little information has been gathered about natural gap dynamics and gap regeneration in these forests. Such knowledge is important for application of near natural silvicultural system, especially irregular shelterwood.

In natural forests dominated by shade-tolerant tree species, regeneration is dependent on several factors such as seed production and dispersal (Wagner 1999), germination and survival (Szwagrzyk et al. 2001), abiotic site factors (Madsen 1995; Madsen and Larsen 1997), canopy openings (Emborg 1998), the competition of under-storey herbal vegetation (Dolling 1996), browsing, individual species performance (Modrý et al. 2003) and seed predation (Birkedal et al. 2009, Löf et al. 2004). In European beech forests, windstorms often create canopy gaps that result in changes in incidental light, soil moisture, and the availability of nutrients on the forest floor (Gálhidy et al. 2006). In general, tree seedlings react positively to increased light levels (Minotta and Pinzauti 1996; Szwagrzyk et al. 2001), which are often initiated by tree fall gaps. Since light is a key growth factor along with water and nutrients (Madsen 1995), the regeneration success in (near) natural forests is often related to structural dynamics and gap formation (Emborg 1998). Furthermore, uprooted trees, which are associated with the absence of a thick holorganic layer, lower herbal competition, crumbled compacted loamy soil, and decreased soil acidity, may create favourable germination sites. In Belgium Muys et al. (1988) recorded the presence of higher seedling densities and seedling height (for both beech and other species) in uprooted zones. Rapid closure of gaps was due to the lateral expansion of existing tree crowns. At the same time, Koop and Hilgen (1987) found that gap-edge trees in France are more subject to decline and tree fall than other trees, presumably due to increased insolation and asymmetric crowns, thus enlarging the gap area. Nonetheless, within the forest cycle of particular forest development stages (Korpel'
1995; Leibundgut 1982), gaps trigger regeneration and thus initiate the next turn of the cycle.

Although substantial research has been done on gap regeneration in beech forests, it has mainly been confined to Atlantic and Baltic Europe (e.g. Collet and Chenost 2006; Koop and Hilgen 1987; Ritter et al. 2005; Madsen and Hahn 2008). In those regions beech is close to the border of its natural distribution, which is manifested in difficulties in natural regeneration (Topoliantz and Ponge 2000). It is likely that in East-Central Europe, with more continental climate the regeneration patterns are different (e.g. gap partitioning), therefore direct transfer of knowledge may be limited. In addition, few studies have investigated within-gap resource heterogeneity, which plays an important role in regeneration processes (Gálhidy et al. 2006; Mountford et al. 2006; Rozenbergar et al. 2007). These studies also indicate that within-gap micro site patterns are variable among site and stand combinations.

The aim of the current study was to investigate the effects of the parent stand on the growth of beech regeneration in conditions characterized by sub-continental climate with low annual precipitation. The research questions this study addresses are as follows: (1) What are the main micro-habitat factors which influence successful natural beech regeneration in the studied conditions? (2) How does gap size and within-gap heterogeneity influence natural beech regeneration in conditions with limited annual precipitation?

\section{Materials and Methods}

\section{Study Area}

The Voděradské bučiny National Nature Reserve (NNR) $\left(49^{\circ} 58^{\prime} \mathrm{N}, 14^{\circ} 48^{\prime} \mathrm{E}\right)$ is situated in Central Bohemia (Czech Republic), 345-501 m a.s.l. The parent rock is granite, and Cambisols of low humus content predominate within the forest stands. According to the nearest climate and precipitation station located at Ŕíčany (401 m a.s.l., $9 \mathrm{~km}$ distance from the study area), mean annual temperature is $7.8^{\circ} \mathrm{C}$ and annual precipitation is $623 \mathrm{~mm}$. In the period from April to September mean temperature is $14.0^{\circ} \mathrm{C}$ and precipitation totals $415 \mathrm{~mm}$. The duration of the vegetation period with mean daily temperature above $10.0^{\circ} \mathrm{C}$ is more than 158 days.

The Voděradské bučiny NNR was established in 1955 on a total area of 658 ha in a former managed forest, including both homogeneous, even-aged beech stands and beech stands of near-natural forest structure. In the same year the reserve was divided into two parts, one with limited forest management and the other with active forest management aimed at the enhancement of diversified forest structure. 
The research was conducted in forest stand located in the first part with continuous protection status ensuring the lowest direct human impact since the establishment of the reserve (only damaged or uprooted trees and snags were to some extend removed till 1991).

\section{Data Collection}

Two permanent research plots (PRP) were established in 2006 to study stand and regeneration dynamics, both $100 \times 100 \mathrm{~m}$ (1 ha) in size; the location of both PRPs was selected in the most differentiated parts of the stand with minimal management interventions in the area (forest stand 417A16a/8a). The site type was classified as forest type complex 4B Fagetum eutrophicum - Nutrient-rich Beech forest (according to the Czech typological system of forest management planning). The age of the over story and under story was 160 and 90 years, respectively. The plots are $470 \mathrm{~m}$ a.s.l. and have a northern exposition and a slope inclination of $10 \%$. Beech comprised $96.0 \%$ and $69.4 \%$ of the total timber volume on PRP 01 and PRP 02, respectively. Total timber volume $(\mathrm{dbh} \geq 7$ $\mathrm{cm}$ over bark) amounted to $707.21 \mathrm{~m}^{3} \mathrm{ha}^{-1}$ (PRP 01) and $505.60 \mathrm{~m}^{3} \mathrm{ha}^{-1}$ (PRP 02). For detailed description of both plots see Bílek et al. (2011). Within PRP 01 and 02 , smaller research plots (RP) were established. In each PRP only one large gap was present, consequently, in each PRP we selected a smaller gap. RP C (canopy) was placed under closed forest stand without gaps in its direct proximity. Within the RPs we established a $5 \times 5 \mathrm{~m}$ grid aligned N-S. At each grid intersection, one $1.5 \times 1.5 \mathrm{~m}$ sample plot $(\mathrm{SP})$ was placed. The expanded gap area was measured as a polygon with the vertices represented by the stem basis of the gap border trees (Table 1).

Furthermore, we evaluated gap resource heterogeneity by dividing the gaps into gap centers (sample plots with all four neighboring plots in direction N, S, E, W) and gap boundaries (sample plots having from 1 to 3 neighbours in the regular grid). The canopy (RP C) was considered as a separate category. Addi-

Table 1. Basic data for research plots (RP) within PRP 01 and 02 (SP - sample plot)

\begin{tabular}{cclccc}
\hline RP & PRP & Location & No. of SPs & $\begin{array}{c}\text { Expanded } \\
\text { gap area } \\
\text { (ha) }\end{array}$ & Exposure \\
\hline A & 01 & Small gap & 23 & 0.04 & $\mathrm{~N}$ \\
C & 01 & Canopy & 34 & $0.06^{*}$ & $\mathrm{~N}$ \\
D & 01 & Large gap & 44 & 0.07 & $\mathrm{~N}$ \\
E & 02 & Large gap & 30 & 0.05 & $\mathrm{~N}$ \\
F & 02 & Small gap & 20 & 0.03 & $\mathrm{~N}$ \\
\hline
\end{tabular}

*area of the sample plot. tionally, the large gap (D) boundary was divided into north and south edges.

Light was measured on 54 sampling plots only within PRP 01 using hemispherical photography. For this we used a Nikon F50 camera equipped with a Sigma $8 \mathrm{~mm}, \mathrm{f} / 4$ fisheye lens which was calibrated to establish the degree of lens distortion (Diaci and Kolar 2000). Light measurements were performed at breast height in completely overcast sky conditions to avoid direct radiation. Photographs were taken with the top of the camera oriented to the north. The film was scanned and the images processed on a computer with Corel PHOTO-PAINT 9 software to acquire quadratic binary images in GIF format. The images were then analyzed by hemIMAGE software (Bruner 2002).

Soil moisture (on 80 sampling plots within PRP 01) measurements were performed using the frequency domain probe (IMAG) that simultaneously measures soil temperature. Sensor was calibrated using soil moisture content values obtained for each soil type by the gravimetric method (Hilhorst 1998; Dirksen 1999). The probe length was $10 \mathrm{~cm}$ and the probe was stuck into the soil surface vertically after removal of the top litter layer. On average, soil moisture was measured three times at each sampling plot. Average values were then used in the final analysis. Measurements were taken in June 2002 after an extended period without heavy rain, to more precisely capture the difference among micro-sites within gaps under stress conditions.

The total thickness of holorganic horizons was measured in opposite corners of the SPs. If unrepresentative features such as stones and stumps were present, measurement was relocated towards the centre of the sample plot. Cover in per cent was visually estimated from above for tree regeneration, total ground vegetation, coarse woody debris (CWD), litter, bare soil, stones, and surface roots. Layering was ignored and the interval for the total cover estimation was $1-100 \%$. In addition, on every SP, cover was visually estimated for each species separately (tree, shrub, and ground vegetation). In this case, layering was included, meaning that the sum for each SP could be well over $100 \%$.

All seedlings and saplings were counted and categorized according to height classes (one-year old seedling, $\leq 20 \mathrm{~cm}, 21-50 \mathrm{~cm}, 51-90 \mathrm{~cm}, 91-130 \mathrm{~cm}$, $131-200 \mathrm{~cm}, 201-300 \mathrm{~cm}, \geq 300 \mathrm{~cm}$ ). In one quadrate of the SP, seedlings and saplings were checked for browsing damage and categorized into one of three damage classes (minor damage $=$ less than $10 \%$ of the shoots browsed, terminal shoot not damaged; moderate damage $=10-50 \%$ of the shoots browsed and/or terminal shoot damaged; severe damage $=$ more than $50 \%$ of shoots browsed including terminal shoot). On each SP the five dominant trees of the 
beech regeneration (if present) were selected and several parameters for each tree were measured or estimated: browsing damage, total stretched length of the stem, previous year's growth, diameter of root collar, stem form (one, two, or multiple stems), and whole plant branching (upright, stem deviation, or plagiotropic). Relative height increment was estimated as the ratio of the previous year's growth to total length.

Co-dominant and dominant mature gap border trees were cored at breast height using an increment borer for the dating of releases and estimation of the age of particular gaps. Cores were mounted and polished and the ring width was then measured to the nearest $0.01 \mathrm{~mm}$ using the measuring device LINT$\mathrm{AB}^{\mathrm{TM}}$ and the software TSAP-Win ${ }^{\mathrm{TM}}$. Cores were aged using a statistical cross-dating technique (Yamaguchi 1991). We analyzed three cores per gap, except RP-F, for which only one spruce core could be analyzed. We used the running means method for release identification by comparing ten-year growth segments and using $50 \%$ increases in growth rates to identify major release events (Nowacki and Abrams 1997; Lorimer and Frelich 1989).

\section{Statistical Analyses}

Data normality was tested using the Shapiro-Wilk normality test. Not all data within groups were normal, therefore the non-parametric Kruskal-Wallis test was used to compare recorded vegetation and environmental variables between research plots, and to compare gap heterogeneity. Post-hoc comparisons of the mean ranks of all pairs of groups were performed. To determine the correlation among particular abiotic factors (direct light, diffuse light, soil moisture, total thickness of holorganic horizons), ground vegetation and regeneration characteristics the Spearman non-parametric correlation coefficient was used. Multiple comparisons for proportions of direct and upright stems among RPs were carried out by using test statistics

$$
T=\frac{\left|p_{i}-p_{j}\right|}{\sqrt{\frac{1}{8}\left(\frac{1}{n_{i}}-\frac{1}{n_{j}}\right)}} \sim q_{k, \infty}, \quad i=1,2, \ldots, k-1, \quad j>i,
$$

(Anděl 1998), where $k$ is number of RPs, $p_{i}$ is proportion of upright stems at $i$-th RP, $n_{i}$ is total number of stems at $i$-th RP and $q_{k, \infty}$ is critical value of Studentized range.

The effects of ecological factors (direct light, diffuse light, soil moisture, total thickness of humus horizons, and ground vegetation cover) on the size and growth of beech regeneration and beech regeneration cover were analysed with linear mixed-effects models (LMMs) (Pinheiro et al. 2013). The models were built with the "nlme" package. RP was considered random factor. Only SPs with complete data were included in the calculation (both light and moisture measurements were performed only on particular plots). In order to check for multicolinearity between independent variables, the values of variance inflation factors (VIF) were calculated. For all independent variables the VIF value was below 1.846. Data were analysed in Statistica 9, Microsoft Excel Version 2003 and R 2.15.0 (R Development Core Team, 2012).

\section{Results}

\section{Within-Gap Resource Heterogeneity}

Values of direct and diffuse light were expressed as the percentage of above-canopy light PACL (Table 2). There was a significant difference in PACL among research plots (Kruskal-Wallis test: $P<0.001$ ) under the canopy (C) and in the small gap (A) and the large gap (D). The large gap (D) clearly showed the highest light input regarding both diffuse and direct components. Light conditions under the closed canopy (C) and the small gap (A) differed mainly with respect to diffuse light and were more similar with respect to direct light, with higher light variability inside the small gap. There was a positive correlation $\left(R_{s}=0.428, P=0.002\right)$ between both light components. Contrary to our expectations, measurements did not show significant differences in soil moisture conditions among large and small gap and below the canopy (Kruskal-Wallis test: d.f. $=2, \mathrm{H}=1.11$, $P=0.575)$. The average value of volumetric moisture content (\%) was highest within the small gap (A - 16.14\%) and the lowest under closed canopy (C $-14.98 \%)$. Within the large gap (D), the average value was $15.58 \%$. Total light input and the thickness of holorganic horizons were significantly negatively correlated $\left(R_{s}=-0.300, P=0.030\right)$. The total thickness of the holorganic horizon significantly differed between gaps and canopy and ranged from 0 to 10 $\mathrm{cm}$. The average thickness ranged from $2.6 \mathrm{~cm}$ in large gap (D) to $3.3 \mathrm{~cm}$ under canopy (C) and $3.4 \mathrm{~cm}$ in small gap (A).

Our approach to the division of SPs within gaps on PRP 01 produced six-staged zoning across the gradient from large gap centre to closed canopy. A marked contrast was observed between factors below canopy and within gaps, with the exception of soil moisture content and ground vegetation cover. Conditions in the centre and in the edges of the small gap were very similar and did not differ in any of the selected variables mentioned in Table 3 . Within the large gap (D) there were significant differences in the height of dominant beeches, these being higher 
Table 2. Percentage of above-canopy light for direct and diffuse light in small gap (A) and large gap (D) and under canopy (C)

\begin{tabular}{lcccccccc}
\hline \multicolumn{1}{c}{ RP } & N & Average \pm SD & Median & Variance & Q25 & Q75 & Min & Max \\
\hline A - small gap & 20 & $3.57 \pm 3.23$ & 2.28 & 10.45 & 1.05 & 6.15 & 0.42 & 9.76 \\
C - canopy & 11 & $4.98 \pm 2.15$ & 5.44 & 5.11 & 3.12 & 6.46 & 1.32 & 8.54 \\
D - large gap & 23 & $15.48 \pm 8.44$ & 16.91 & 71.30 & 5.84 & 23.28 & 2.37 & 28.00 \\
\hline & & & Direct solar radiation $\%$ & & & \\
\hline A - small gap & 20 & $10.51 \pm 2.36$ & 10.58 & 5.5492 & 8.52 & 11.69 & 6.74 & 16.20 \\
C - canopy & 11 & $5.61 \pm 1.09$ & 5.82 & 1.3029 & 4.464 & 6.31 & 4.07 & 7.88 \\
D - large gap & 23 & $16.06 \pm 4.35$ & 15.30 & 18.943 & 12.45 & 20.27 & 9.35 & 24.10 \\
\hline
\end{tabular}

Note: N - number of SPs, where measurement was performed, SD - standard deviation, Q25 - lower quartile, Q75 - upper quartile, Min - Minimal value, Max - Maximal value

in the gap centre, and in relative height increment, which was greater along the north boundary. Values of direct light in the centre of the large gap and in the north edge of the large gap (D) were significantly different from both, values in the small gap edges and the small gap centre (A). Between the south and the north edge of the large gap (D), no significant differences were determined. The north edge of the large gap (D) was characterized by high levels of direct PACL (they were comparable to those of the gap centre), and to lower rates of diffuse PACL. The lowest moisture levels were measured here, as well as low levels of ground vegetation coverage, but these differences were not statistically significant. Regeneration cover and the number of beech trees were somewhat higher in the large gap centre. In contrast, in the south position the cover of graminoids was highest among the positions within gap and number of beeches under $50 \mathrm{~cm}$ was the lowest there (with the exception of full canopy). Regarding the characteristics of dominant beech individuals, significant differences were confirmed between heights and relative height increment. The height of beech regeneration was the highest in the gap centres and the lowest in the north edge of the large gap. Conversely, relative height increment was lowest in the gap centres and highest along the north-oriented gap boundary of the large gap.

\section{Cover of SPs}

In general, the regeneration cover was the highest in small gaps, decreased in large gaps, and was the lowest below canopy. A substantial percentage of litter cover on all RPs was reported, while an almost complete cover of litter occurred under the canopy. Bare soil, stones, and roots were scarce. A general overview with average and median values is given in Table 4.

On PRP 01, a total of 30 plant species were found (5 tree species: beech, hornbeam, sycamore maple, spruce, larch; 1 shrub; 3 ferns; 11 grasses; 1 moss; and 9 herbs). More plant species were present in gaps (RP A - 21 sp.; RP D - 23 sp.) than under closed canopy (RP C - $17 \mathrm{sp}$.$) . Total ground vegetation cover was$ higher inside gaps (RP A - 64.7\%; RP D - 48.3\%) than below canopy (RP C $-9.3 \%$ ). RP A (small gap) and D (large gap) were dominated by beech $(46.4 \%$ and $17.5 \%$, respectively). Below canopy, beech was present on $44.1 \%$ of SPs, but average cover was only $2.6 \%$. Within the large gap, hornbeam represented a substantial contribution to tree regeneration $(29.0 \%)$. The regeneration was clearly dominated by beech, representing $75.8 \%$ of all individuals. Hornbeam was the second most abundant species, representing $15.5 \%$ of all individuals. Table 5 shows data on tree species regeneration for individual RPs. In large gap (D) the per cent ratio of grass species was considerable $-21.9 \%$ (compared to $4.4 \%$ on RP C and $4.2 \%$ on RP A). Calamagrostis epigejos L. covered $12.4 \%$ and Calamagrostis arundinacea L. covered $4.9 \%$. Carpinus betulus L. and Athyrium filix-femina L. each covered more than $1.0 \%$. Large gap (D) was also characterized by the highest cover of grass species. In contrast, RP C - canopy was marked by the highest number of herbs but had the lowest total ground vegetation cover.

On PRP 02, the average total ground vegetation cover was $26.1 \%$ in large gap (E) (17 plant species: 1 tree species, 5 herbs, 8 grasses, 2 ferns, 1 moss) and $28.8 \%$ in small gap (F) (14 plant species: 1 tree species, 5 herbs, 6 grasses, 1 fern, 1 moss). Beech was the only tree species which dominated tree regeneration (average cover RP E - 18.9\%, RP F - 26.4\%; present on $86.2 \%$ and $90.0 \%$ of sample plots respectively). In large gap (E) mosses nearly reached an average cover of $2.0 \%$, followed by Calamagrostis epigejos L., covering $1.8 \%$.

Total ground vegetation cover was positively correlated with soil moisture content $\left(R_{s}=0.381, P=\right.$ $0.005)$ and diffuse light $\left(R_{s}=0.309, P=0.026\right)$. Graminoids were positively correlated with diffuse 


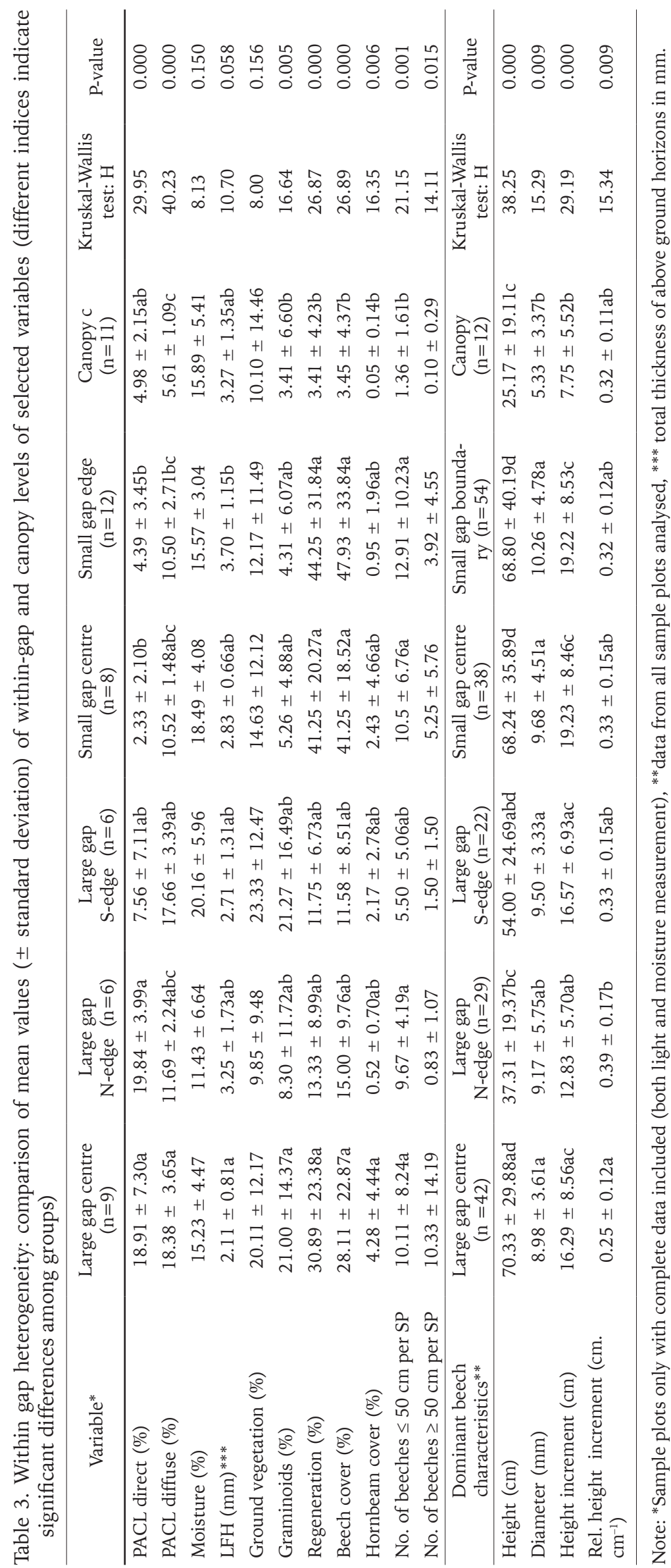


Table 4. Average and median cover on research plots

\begin{tabular}{|c|c|c|c|c|c|c|c|}
\hline & Nr. of SPs & $\%$ & Regeneration & $\begin{array}{c}\text { Ground vege- } \\
\text { tation }\end{array}$ & CWD & Litter & Other \\
\hline \multirow[t]{2}{*}{ A - small gap } & 23 & average & 43.96 & 11.96 & 1.31 & 41.75 & 1.09 \\
\hline & & median & 40.00 & 8.00 & 0.30 & 40.00 & 0.00 \\
\hline \multirow[t]{2}{*}{ C - canopy } & 33 & average & 2.50 & 6.32 & 4.92 & 84.74 & 1.52 \\
\hline & & median & 0.00 & 2.00 & 4.00 & 89.00 & 0.00 \\
\hline \multirow[t]{2}{*}{ D - large gap } & 44 & average & 17.85 & 23.57 & 2.00 & 52.95 & 3.63 \\
\hline & & median & 10.00 & 20.00 & 0.10 & 52.95 & 0.00 \\
\hline \multirow[t]{2}{*}{ E - large gap } & 29 & average & 18.91 & 6.11 & 12.76 & 54.46 & 7.76 \\
\hline & & median & 10.00 & 2.00 & 5.00 & 51.00 & 0.00 \\
\hline \multirow[t]{2}{*}{ F - small gap } & 20 & average & 26.35 & 1.58 & 4.35 & 62.04 & 5.68 \\
\hline & & median & 20.00 & 0.50 & 2.50 & 71.00 & 0.00 \\
\hline
\end{tabular}

Note: CWD - Coarse woody debris, Other - bare soil, stones and surface roots.

light $\left(R_{s}=0.483, P=0.000\right)$, ferns were negatively correlated with direct light $\left(R_{s}=-0.362, P=0.008\right)$ and positively correlated with soil moisture $\left(R_{s}=\right.$ $0.442, P=0.001)$. There was a significant correlation of graminoids cover with the diameter, height, and absolute height increment of dominant beeches $\left(R_{s}\right.$ $=-0.180, P=0.011 ; R_{\mathrm{s}}=-0.217, P=0.002 ; R_{\mathrm{s}}=$ $-0.279, P=0.000$ ), whereas herbs cover was significantly correlated only with the diameter of beeches $\left(R_{s}=-0.159, P=0.026\right)$.

\section{Characteristics of Beech Regeneration}

The highest density of beech regeneration was found in small gaps (RP A and RP F), with the highest tree density in the $3^{\text {rd }}$ height class $(21-50 \mathrm{~cm})$. Similar height development with lower densities was recorded within large gaps (RP D and RP E). The lowest density of beech regeneration was under closed canopy (the majority of individuals in $2^{\text {nd }}$ height class) - (Fig. 1). We did not record any oneyear-old seedlings in a given year.

In the large gaps (D and E) and small gap (A) a considerable percentage of beech regeneration reached the $4^{\text {th }}$ height class. In small gap (F) a considerable number of plants in the $7^{\text {th }}$ and $8^{\text {th }}$ height classes were found (667 and 222 individuals per ha resp.). More advanced beech regeneration seemed to be clustered within small gaps (A and F), indicating that the gap was older $(\mathrm{A})$ or that the regeneration had already been established before the gap creation (F). However, the presence of taller plants did not lower the density of younger beech regeneration within the small gaps.

The most important factors influencing the cover of beech regeneration and the performance of dominant beech trees were diffuse and direct light and the presence of ground vegetation (Table 6). Descriptive characteristics of the dominant individuals of the beech regeneration on RPs are given in Table 7 .

Table 5 . Average density of tree regeneration per 1 ha on research plots (RP)

\begin{tabular}{lccccc}
\hline \multirow{2}{*}{ Species } & RP A & RP C & RP D & RP E & RP F \\
\cline { 2 - 6 } & Average \pm SD (ind.) & Average \pm SD (ind.) & Average \pm SD (ind.) & Average \pm SD (ind.) & Average \pm SD (ind.) \\
\hline Fagus sylvatica & $71,111 \pm 44,771$ & $9,020 \pm 16,541$ & $51,414 \pm 56,253$ & $54,713 \pm 68,675$ & $75,778 \pm 75,181$ \\
Carpinus betulus & $78.63 \%$ & $95.85 \%$ & 69.34 & $100.00 \%$ & $100.00 \%$ \\
& $5,411 \pm 9,263$ & $130 \pm 750$ & $21,414 \pm 29,439$ & 0 & 0 \\
Picea abies & $5.98 \%$ & $1.38 \%$ & 28.88 & $0.00 \%$ & $0.00 \%$ \\
& $8,117 \pm 8,659$ & $261 \pm 1,045$ & $909 \pm 2,238$ & 0 & 0 \\
Larix decidua & $8.98 \%$ & $2.77 \%$ & $1.23 \%$ & $0.00 \%$ & $0.00 \%$ \\
& $773 \pm 2,134$ & 0 & $404 \pm 1,277$ & 0 & 0 \\
Acer pseudoplatanus & $0.85 \%$ & $0 \%$ & $0.54 \%$ & $0.00 \%$ & $0.00 \%$ \\
& $5,024 \pm 9,047$ & 0 & 0 & $0.00 \%$ & 0 \\
Total & $5.55 \%$ & $0.00 \%$ & $0.00 \%$ & 54,713 & $0.00 \%$ \\
\hline
\end{tabular}

Note: SD - standard deviation; ind. - individuals. 


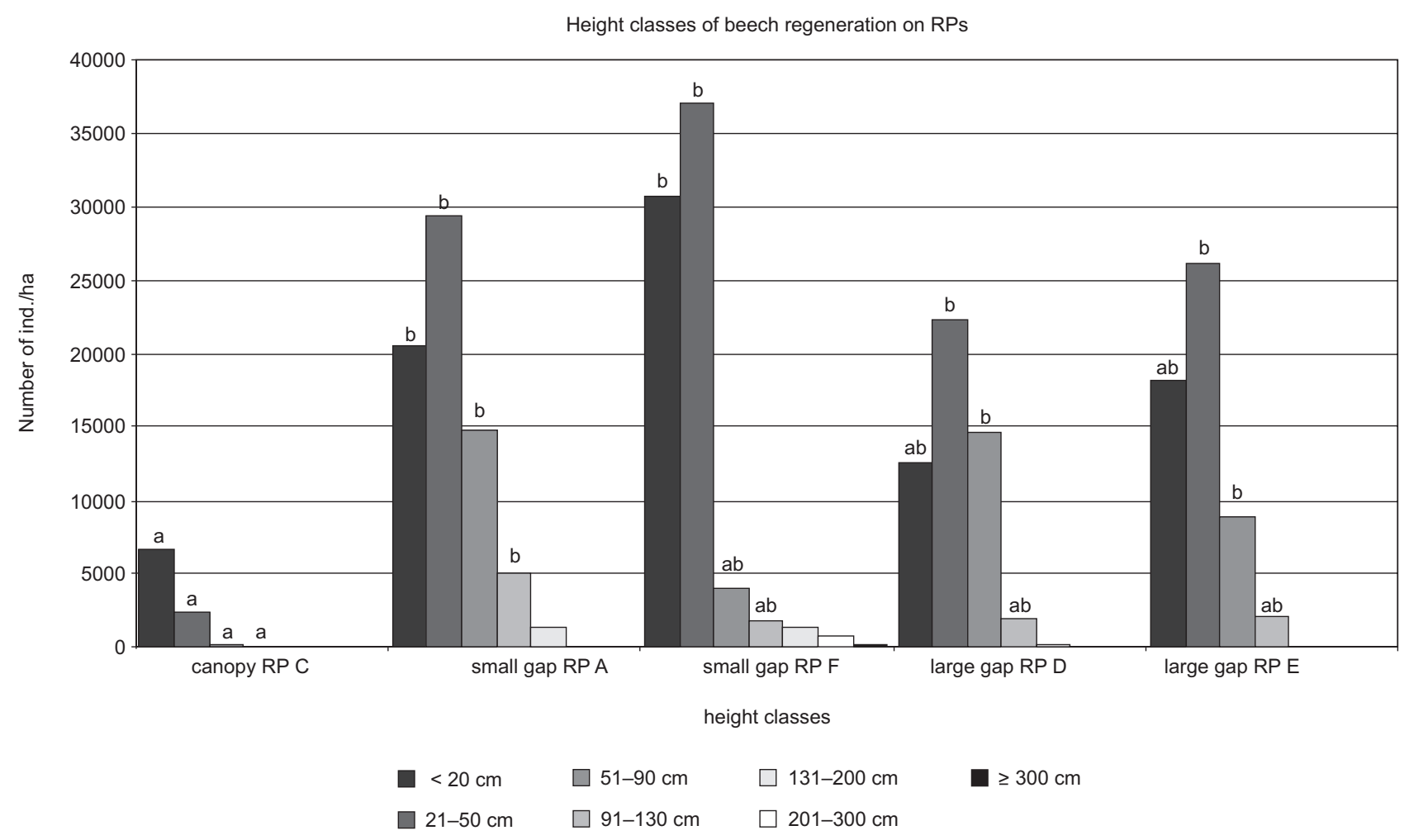

Fig. 1. Height classes of beech regeneration on research plots (RP) (one-year-old seedlings are not displayed)

An ungulate browsing inventory was performed in June and September. In general, the damage caused by browsing increased during the vegetation period, but the differences were not significant (only the $2^{\text {nd }}$ inventory is presented). Greater damage on beech saplings was recorded within gaps (for moderate damage ranging from $13.3 \%$ to $21.0 \%$ of the number of plants). Beech was browsed heavily only in large gap D $(0.9 \%)$ and small gap F $(4.1 \%)$. Under canopy only $7.7 \%$ of beech showed moderate damage; the rest were not browsed or showed only minor damage. In general, the browsing pressure on hornbeam was higher $(7.1 \%$ heavy damage and $28.6 \%$ moderate damage). Little browsing was recorded on spruce.

The ratio of beech individuals of direct stem ranged from $44.9 \%$ to $50.6 \%$ with the exception of PRP E with distinctly above-average proportion of plants without stem branching (68.0\%). Nevertheless statistically significant differences were recorded only between $\mathrm{RP}_{\mathrm{S}} \mathrm{A}$ end $\mathrm{E}$, and $\mathrm{RP}_{\mathrm{S}} \mathrm{D}$ and $\mathrm{E}(T=$ $0.231, Q=0.178$ and $T=0.235, Q=0.160$ resp.). More expressed differences among RPs were recorded with respect to the overall plant branching (Table 8 ). Beech regeneration of poor quality was recorded mainly under canopy $(C)$, where there was an absence of upright individuals, and the majority of individuals had stem deviations (knee-shaped growth) and plagiotropic growth. In gaps the ratio of upright individuals ranged from $31.1 \%$ to $58.0 \%$.

\section{Gap Age}

On PRP 01, a major release event was dated at the end of the 1940s and at the beginning of the 1950s. This release event probably contributed to the development of the complex forest structure on PRP 01; nevertheless, moderate release events after 1984 were crucial for the development of beech regeneration (originating mostly from the mast year in 1993). On PRP 02, the release events of particular trees did not coincide and we therefore assumed that the large gap originated from the last release event in the late 1980s and early 1990s. Spruce border trees (RP F small gap) indicate a release event in 1982. In general we can assume that canopy gaps on PRP 01 and PRP 02 originated from the period between 1982 and 1992.

\section{Discussion}

Under small gaps the combination of moderate levels of diffuse light and relatively low levels of direct light created more favourable conditions for the establishment and growth of shade-tolerant forest regeneration (Wagner et al. 2011; Diaci 2002). In our study diffuse light availability influenced the beech seedling height and diameter positively; ground vegetation influenced these dependent variables negatively. Small gaps (RPs A and F) showed both the highest 
Table 6. Regression statistics for selected dependent variables: Diameter $=$ diameters of root collar of dominant beeches on sample plots (SP), Height $=$ heights of dominant beeches on SPs, Height increment $=$ absolute height increment of dominant beeches on SPs, Relative height increment = relative height increment of dominant beeches on SPs, Cover of beech $=$ ratio of beech regeneration on SPs. In several cases less than five dominant beeches were present on SP. Missing data were casewise deleted.

\begin{tabular}{|c|c|c|c|c|}
\hline Dependent Variable & Independent Variables & Regression coefficient & P-value & Regression Statistics \\
\hline Diameter & $\begin{array}{l}\text { Intercept A } \\
\text { Intercept C } \\
\text { Intercept D } \\
\text { PACL Direct } \\
\text { PACL Diffuse } \\
\text { Moisture } \\
\text { LFH (mm) } \\
\text { Ground vegetation }\end{array}$ & $\begin{array}{r}9.094 \\
6.930 \\
7.963 \\
-0.062 \\
0.295 \\
-0.057 \\
0.099 \\
-0.117\end{array}$ & $\begin{array}{l}0.000 \\
0.000 \\
0.000 \\
0.285 \\
0.001 \\
0.409 \\
0.683 \\
0.000\end{array}$ & $\begin{array}{c}\mathrm{F}=6.224 \\
\mathrm{DF}_{\mathrm{R}}=189 \\
\mathrm{DF}_{\mathrm{M}}=7 \\
\mathrm{p}-\mathrm{value}^{=}=1.4 .10^{-6} \\
\mathrm{R}^{2}=0.187\end{array}$ \\
\hline Height & $\begin{array}{l}\text { Intercept A } \\
\text { Intercept C } \\
\text { Intercept D } \\
\text { PACL Direct } \\
\text { PACL Diffuse } \\
\text { Moisture } \\
\text { LFH (mm) } \\
\text { Ground vegetation }\end{array}$ & $\begin{array}{r}63.984 \\
33.727 \\
45.939 \\
0.009 \\
1.694 \\
0.742 \\
-3.032 \\
-1.236 \\
\end{array}$ & $\begin{array}{l}0.001 \\
0.001 \\
0.001 \\
0.983 \\
0.010 \\
0.134 \\
0.087 \\
0.000 \\
\end{array}$ & $\begin{array}{c}\mathrm{F}=10.757 \\
\mathrm{DF}_{\mathrm{R}}=189 \\
\mathrm{DF}_{\mathrm{M}}=7 \\
\mathrm{p} \text {-value }=2.2 .10^{-11} \\
\mathrm{R}^{2}=0.285\end{array}$ \\
\hline Height increment & $\begin{array}{l}\text { Intercept A } \\
\text { Intercept C } \\
\text { Intercept D } \\
\text { PACL Direct } \\
\text { PACL Diffuse } \\
\text { Moisture } \\
\text { LFH (mm) } \\
\text { Ground vegetation }\end{array}$ & $\begin{array}{r}19.558 \\
9.979 \\
16.660 \\
-0.073 \\
0.162 \\
0.214 \\
-0.526 \\
-0.283\end{array}$ & $\begin{array}{l}0.000 \\
0.000 \\
0.000 \\
0.502 \\
0.310 \\
0.075 \\
0.220 \\
0.000\end{array}$ & $\begin{array}{c}\mathrm{F}=10.129 \\
\mathrm{DF}_{\mathrm{R}}=189 \\
\mathrm{DF}_{\mathrm{M}}=7 \\
\mathrm{p} \text {-value }=9.6 .10^{-11} \\
\mathrm{R}^{2}=0.273\end{array}$ \\
\hline Relative height increment & $\begin{array}{l}\text { Intercept A } \\
\text { Intercept C } \\
\text { Intercept D } \\
\text { PACL Direct } \\
\text { PACL Diffuse } \\
\text { Moisture } \\
\text { LFH (mm) } \\
\text { Ground vegetation }\end{array}$ & $\begin{array}{l}0.312 \\
0.312 \\
0.312 \\
0.001 \\
0.006 \\
0.000 \\
0.014 \\
0.002\end{array}$ & $\begin{array}{l}0.000 \\
0.000 \\
0.000 \\
0.408 \\
0.031 \\
0.966 \\
0.079 \\
0.048\end{array}$ & $\begin{array}{c}\mathrm{F}=2.809 \\
\mathrm{DF}_{\mathrm{R}}=189 \\
\mathrm{DF}_{\mathrm{M}}=7 \\
\mathrm{p} \text {-value }=0.008 \\
\mathrm{R}^{2}=0.094\end{array}$ \\
\hline Cover of beech & $\begin{array}{l}\text { Intercept A } \\
\text { Intercept C } \\
\text { Intercept D } \\
\text { PACL Direct } \\
\text { PACL Diffuse } \\
\text { Moisture } \\
\text { LFH (mm) } \\
\text { Ground vegetation }\end{array}$ & $\begin{array}{r}53.195 \\
17.494 \\
31.311 \\
-0.205 \\
0.732 \\
-0.522 \\
0.171 \\
-0.682\end{array}$ & $\begin{array}{l}0.076 \\
0.076 \\
0.076 \\
0.728 \\
0.435 \\
0.415 \\
0.942 \\
0.012\end{array}$ & $\begin{array}{c}\mathrm{F}=7.400 \\
\mathrm{DF}_{\mathrm{R}}=44 \\
\mathrm{DF}_{\mathrm{M}}=7 \\
\mathrm{p} \text {-value }=7.2 .10^{-6} \\
\mathrm{R}^{2}=0.541\end{array}$ \\
\hline
\end{tabular}

Note: PACL - percentage of above-canopy light, LFH $(\mathrm{mm})$ - total thickness of above ground horizons in mm.

cover of beech regeneration and the highest density of individuals per ha. The superiority of small gaps was further confirmed with respect to the growth characteristics of dominant individual beech trees and height growth. Results of this study are similar to results of Mountford et al. (2006) and Gálhidy et al. (2006) who found more prolific beech regeneration in small and medium gaps and are in accordance with conclusions of Bolte et al. (2007), who stressed the importance of soil water resource management through adequate beech regeneration in small gap openings. On the contrary Madsen and Hahn (2008) didn't confirm gap partitioning of regeneration and stressed the importance beech advance regeneration.
In the larger gaps, the N-S asymmetry was of particular importance. The northern margin of the large gap (D) received the highest direct light levels, whereas soil moisture values were the lowest. The latter was probably a result of high temperatures, high evaporation, and root competition from gap edge trees. This unfavourable combination of ecological factors can explain the small regeneration size and the poor absolute height increment of beech regeneration (see Diaci 2002) as well as the limited cover of ground vegetation here. The main reason for the rather homogenous conditions in small gaps was probably the limited area of the canopy opening, the limited number of soil and moisture measurements, 
Table 7. Descriptive characteristics of the dominant individuals of the beech regeneration on research plots (RP)

Heights of dominant trees of beech regeneration

\begin{tabular}{|c|c|c|c|c|c|c|}
\hline $\mathrm{RP}$ & $\mathrm{N}$ & Average $\pm \mathrm{SD}(\mathrm{cm})$ & Median $(\mathrm{cm})$ & Variance & Min & Max \\
\hline A - small gap & 106 & $72.13 \pm 41.26$ & 70.00 & 1702.76 & 12.00 & 180.00 \\
\hline $\mathrm{C}$ - canopy & 39 & $21.85 \pm 11.55$ & 20.00 & 133.31 & 8.00 & 85.00 \\
\hline $\mathrm{D}$ - large gap & 176 & $53.98 \pm 27.42$ & 48.50 & 752.12 & 12.00 & 140.00 \\
\hline E - large gap & 103 & $60.94 \pm 31.82$ & 57.00 & 1012.25 & 18.00 & 174.00 \\
\hline $\mathrm{F}$ - small gap & 81 & $68.52 \pm 52.81$ & 50.00 & 2788.92 & 14.00 & 247.00 \\
\hline \multicolumn{7}{|c|}{ Last year growth of dominant trees of beech regeneration } \\
\hline $\mathrm{RP}$ & $\mathrm{N}$ & Average \pm SD $(\mathrm{cm})$ & Median $(\mathrm{cm})$ & Variance & Min & $\operatorname{Max}$ \\
\hline A - small gap & 106 & $19.81 \pm 8.54$ & 20.00 & 72.89 & 3.00 & 38.00 \\
\hline C - canopy & 39 & $6.96 \pm 4.09$ & 6.00 & 16.75 & 0.50 & 23.00 \\
\hline D - large gap & 176 & $14.59 \pm 7.18$ & 15.00 & 51.55 & 0.00 & 32.00 \\
\hline E - large gap & 103 & $16.35 \pm 8.27$ & 17.00 & 68.32 & 0.00 & 36.00 \\
\hline F - small gap & 81 & $15.02 \pm 12.61$ & 12.00 & 158.91 & 0.00 & 53.00 \\
\hline \multicolumn{7}{|c|}{ Diameter of root collar of dominant trees of beech regeneration } \\
\hline $\mathrm{RP}$ & $\mathrm{N}$ & Average $\pm \mathrm{SD}(\mathrm{mm})$ & Median (mm) & Variance & Min & Max \\
\hline A - small gap & 106 & $10.12 \pm 4.62$ & 10.00 & 21.34 & 2.00 & 25.00 \\
\hline C - canopy & 39 & $4.89 \pm 2.38$ & 5.00 & 5.67 & 1.00 & 15.00 \\
\hline D - large gap & 176 & $8.74 \pm 4.40$ & 8.00 & 19.37 & 0.50 & 25.00 \\
\hline E - large gap & 103 & $8.70 \pm 4.34$ & 7.60 & 18.83 & 2.70 & 24.10 \\
\hline F - small gap & 81 & $9.36 \pm 4.99$ & 8.00 & 24.92 & 2.10 & 24.60 \\
\hline
\end{tabular}

Note: N - Number of measured individuals, SD - standard deviation, Min - Minimal value, Max - Maximal value.

and the presence of advanced beech regeneration in the area of the whole canopy opening.

Despite the fact that multiple regression of the selected variables accounted for less than $30 \%$ of the variation in the size of dominant trees of the beech regeneration, the high relative contribution of ground vegetation cover in the prediction of dominant beech size indicated that even established beech regeneration was considerably influenced by the presence of ground vegetation cover (i.e. competition for resources), whereas moisture and the thickness of above ground horizons may play a crucial role in the establishment and early development of beech regeneration. In particular, Calamagrostis epigejos represented a major competitor (Wagner et al. 2011) which negatively impacted beech regeneration development. Therefore, under the given conditions, the control of competitors should be directed primarily at this species.

Differences between gap and canopy soil moisture conditions may be extremely weather dependent where precipitation plays a major role. Normally, variance of soil moisture content is expressed more during periods of drought which negatively influence the survival rates of beech regeneration. Although the measurement of soil moisture content was performed in a distinctly above average precipitation period (monthly total precipitation in the given year was $112.2 \mathrm{~mm}$, whereas average monthly total precipitation between 1960 and 1995 amounted to 87.2 $\mathrm{mm}$ ), the precipitation during the 10 preceding days amounted to only $13.8 \mathrm{~mm}$. Moisture conditions were similar in the centres of the gaps (A and D), around the gaps, and below the closed canopy. Also Gálhidy

Table 8. Statistical differences in number of upright individuals of beech regeneration on research plots (RP).

\begin{tabular}{lcccc}
\hline $\begin{array}{c}\text { Pairs of RPs/*statistical } \\
\text { significance }\end{array}$ & Difference & Test statistic T & Critical value Q & Significance value \\
\hline RP A - C* & 0.358 & 0.642 & 0.241 & 0.000 \\
RP A - D & -0.124 & 0.126 & 0.158 & 0.240 \\
RP A - E & 0.048 & 0.051 & 0.178 & 0.949 \\
RP A - F* & -0.222 & 0.224 & 0.180 & 0.021 \\
RP C - D & -0.483 & 0.768 & 0.228 & 0.000 \\
RP C - E* & -0.311 & 0.591 & 0.242 & 0.000 \\
RP C - F* & -0.580 & 0.866 & 0.251 & 0.000 \\
RP D - E* & 0.172 & 0.177 & 0.160 & 0.035 \\
RP D - F & -0.097 & 0.098 & 0.173 & 0.592 \\
RP E - F* & -0.270 & 0.275 & 0.191 & 0.002 \\
\hline
\end{tabular}


et al. (2006) showed that the maximum soil moisture was the same in small gaps and large gaps. Generally, the pattern of soil moisture is more spatially variable and microrelief-dependent than light (Madsen and Hahn 2008). Moreover, light environment induce changes in soil conditions and the absence of parent trees may both increase soil moisture (Gálhidy et al. 2006). In their companion study in near natural forest of Voděradské bučiny conduced on PRP 01, Podrázský and Remeš $(2006,2007)$ showed that the amount of dry matter decreased by ca. $25 \%$ several years after the canopy opening, especially in the $\mathrm{H}$ horizon, the $\mathrm{pH}$, base content and base saturation increased, as well as the content of macronutrients (with the exception of total calcium). The results proved considerable changes in the humus forms during the natural forest development related to gap dynamics. In gaps, moisture and nutrient status may be particularly favourable for drought sensitive European beech seedlings when young individuals compete with surrounding ground vegetation (Bolte et al. 2007). Gessler et al. 2004 showed that not only water shortage has a negative effect on European beech water budget but it also constrains its nitrogen supply.

Light conditions may also positively influence the growth response of beech seedlings to soil fertility. In low light environments, this response is reduced, whereas in non-limiting light conditions, seedling growth is markedly influenced by nutrient availability (Minotta and Pinzauti 1996). Even at 5\% relative light intensity (RLI) Madsen (1995) found that light was the main factor in limiting growth, which in this study corresponds to values found below closed canopy with sparse woody regeneration. In these light conditions beech reduced its height growth by a factor of two to three (compared to RPs under gaps), but the density of beech regeneration in RP C was still higher than the recommended afforestation rate of this commercial species $\left(5,000-10,000\right.$ ind. ha ${ }^{-1}$ according to Burschel and Huss 1997). Collet et al. (2001) indicated an annual beech seedling height increment of $1.2 \mathrm{~cm}$ as the threshold value for seedling growth necessary for survival in shade conditions. Even in the poorest light conditions within our research plots, the average height increment of beech trees dominating the regeneration reached a value of $6.96 \mathrm{~cm}$ year $^{-1}$. The gap environment resulted in higher values of total height and the diameter of the root collar of beech individuals growing under open canopy. A significant shift in the distribution of height classes of beech regeneration (under the canopy the majority of beech individuals were in the $2^{\text {nd }}$ height class, whereas they were in the $3^{\text {rd }}$ height class on all other plots) corresponds with this observation.

On the contrary, increased direct light under gaps leads to higher herbal vegetation cover and thus increased competition for resources (Modrý et al.
2004). However, in this study ground vegetation cover was instead related to diffuse light and soil moisture content. In the large gap (RP D), a noticeably higher cover of total ground vegetation as a possible reaction to higher direct light input was observed.

While heavier ungulate browsing was recorded in gaps with higher densities of beech seedlings, lower plant densities and the absence of other tree species made the RP C below canopy less attractive to ungulate browsers. In the study area, roe deer (Capreolus capreolus L.) is the most important browser. Although its densities vary during the year, they normally do not exceed 4.0 ind. $100 \mathrm{ha}^{-1}$ (on average 3.5 ind. $100 \mathrm{ha}^{-1}$ ).

No clear difference between beech regeneration quality in small and in big gaps was observed, nevertheless under the closed canopy, the absence of upright individuals and the majority of knee-shaped individuals with a tendency to twin stem underscores the importance of light environment management for the form and quality of beech regeneration. This is mainly relevant for commercial forests. Beech has decurrent growth, and its growing space has a strong influence on the form of the leader. Differences in the allocation of photosynthates lead to differences in tree architecture (Collet et al. 2002). Most stem forking and leaning stems occurred where above-canopy light was below $20 \%$ (see Stancioiu and O'Hara 2006).

\section{Conclusions}

The performance of tree seedlings was influenced by different light levels as a result of gap formation as described in the forest cycle model. Radiation also has an indirect and often contradictory influence on the establishment and growth of tree regeneration via changes in water and nutrient availability, inducing changes in ground vegetation cover and competition for resources. Besides these factors, an important feature may be the dynamics and local history of gap creation with a direct impact on the establishment and future structure of woody regeneration and the interplay of other factors such as the presence of seed years, biotic and abiotic damage, and macroclimatic conditions. Moreover, the indicated negative effects of direct light at the northern gap margin suggest that the extension of gaps in similar managed forest should proceed in the direction of the southern gap border. The results of this study also suggest that it is important that future research of natural regeneration of beech in low precipitation conditions integrates the continuous soil moisture regime and its role in micro-habitat heterogeneity, where periods of drought may play crucial role both in the survival of beech regeneration and ground vegetation. This case study indicates that for the purposes of close- 
to-nature forestry, the gap size corresponding to the removal of one to three large beech trees seems to be, in the given conditions (characterized by lower annual precipitation), a minimal measure to ensure natural beech regeneration with a tolerable level of competition of ground vegetation.

\section{Acknowledgements}

This research project was supported by the Ministry of Agriculture of the Czech Republic, Project No. QI $102 A 085$.

\section{References}

Anděl J. 1998. Statistické metody. Matfyzpress, Praha, $274 \mathrm{pp}$.

Birkedal M., Fischer A., Karlsson M., Löf M., Madsen P. 2009. Rodent impact on establishment of direct-seeded Fagus sylvatica, Quercus robur and Quercus petraea on forest land. Scandinavian Journal of Forest Research 24: 298-307.

Bílek L., Remeš J., Zahradník D. 2011. Managed vs. unmanaged. Structure of beech forest stands ( $F a$ gus sylvatica L.) after 50 years of development, Central Bohemia. Forest Systems 20: 122-138.

Bolte A., Czajkowski T., Kompa T. 2007. The north-eastern distribution range of European beech - a review. Forestry 80: 413-429.

Brunner A. 2002. Manual: Hemispherical photography and image analysis with hemIMAGE and Adobe Photoshop (15.09.2002). Danish Forest and Landscape Research Institute, Denmark, 15 pp.

Burschel P., Huss J. 1997. Grundriß des Waldbaus: ein Leitfaden für Studium und Praxis. 2. Aufl. Parey Buchverlag, Berlin, 487 pp.

Collet C., Lanter O., Pardos M. 2001. Effects of canopy opening on height and diameter growth in naturally regenerated beech seedlings. Annals of Forest Science 58: 127-134.

Collet C., Lanter O., Pardos M. 2002. Effects of canopy opening on the morphology and anatomy of naturally regenerated beech seedlings. Trees 16:291-298. http://dx.doi.org/10.1007/s00468001-0159-x

Collet C., Chenost C. 2006. Using competition and light estimates to predict diameter and height growth of naturally regenerated beech seedlings growing under changing canopy conditions. Forestry 79: 489-502.

Diaci J. 2002. Regeneration dynamics in a Norway spruce plantation on a silver fir-beech forest site in the Slovenian Alps. Forest Ecology and Management 161:27-38.
Diaci J., Kolar U. 2000. Umerjanje objektiva „ribje oko" za fotografijo hemisfere. Zbornik gozdarstva in lesarstva 61: 5-25.

Dirksen C. 1999. Soil Physics Measurements. Catena Verlag GMBH, Reiskirchen, Germany, pp. 39-41.

Dolling A.H.U. 1996. Interference of bracken (Pteridium aqulinum L. Kuhn) with Scots pine (Pinus sylvestris L.) and Norway spruce (Picea abies L. Karst.) seedling establishment. Forest Ecology and Management 88: 227-235.

Emborg J. 1998. Understorey light conditions and regeneration with respect to the structural dynamics of a near-natural temperate deciduous forest in Denmark. Forest Ecology and Management 106: 83-95.

Gálhidy L., Mihók B., Hagyó A., Rajkai K., Standovár T. 2006. Effects of gap size and associated changes in light and soil moisture on the understorey vegetation of a temperate deciduous forest. Plant Ecology 183: 133-145.

Gessler A., Keitel C., Nahm M., Rennenberg H. 2004. Water shortage affects the water and nitrogen balance in central European beech forests. Plant Biology 6: 289-298.

Hilhorst M.A. 1998. Dielectric characterisation of soil. Doctoral Thesis. Wageningen Agriculture University pp. 69-71.

Koop H., Hilgen P. 1987. Forest dynamics and regeneration mosaic shifts in unexploited beech (Fagus sylvatica) stands at Fontainebleau (France). Forest Ecology and Management. 20: 135-150.

Korpel' S. 1995. Die Urwälder der Westkarpaten. Gustav Fischer Verlag, Stuttgart.

Leibundgut H. 1982. Europäische Urwälder der Bergstufe. Haupt, Bern-Stuttgart.

Löf M., Thomsen A., Madsen P. 2004. Sowing and transplanting of broadleaves (Fagus sylvatica L., Quercus robur L., Prunus avium L. and Crataegus monogyna Jacq.) for afforestation of farmland. Forest Ecology and Management 188: 113-123.

Lorimer C.G., Frelich L.E. 1989. A methodology for estimating canopy disturbance frequency and intensity in dense temperate forest. Canadian Journal of Forest Research 19: 651-653.

Madsen P. 1995. Effects of soil water content, fertilization, light, weed competition and seedbed type on natural regeneration of beech Fagus sylvatica. Forest Ecology and Management 72: 251-264.

Madsen P., Hahn K. 2008. Natural regeneration in a beech-dominated forest managed by close-to-nature principles - a gap cutting based experiment. Canadian Journal of Forest Research 38: 17161729.

Madsen P., Larsen J.B. 1997. Natural regeneration of beech Fagus sylvatica L. with respect to canopy density, soil moisture and soil carbon content. Forest Ecology and Management 97: 95-105. 
Minotta G., Pinzauti S. 1996. Effects of light and soil fertility on growth, leaf chlorophyll content and nutrient use efficiency of beech (Fagus sylvatica L.) seedlings. Forest Ecology and Management 86: 61-71.

Modrý M., Hubený D., Rejšek K., 2004. Differential response of naturally regenerated European shade tolerant tree species to soil type and light availability. Forest Ecology and Management. 188: 185-195.

Mountford E.P., Savill P.S., Bebber D.P. 2006. Patterns of regeneration and ground vegetation associated with canopy gaps in a managed beechwood in southern England. Forestry 79: 389-408.

Muys B., van den Berge K., Roskams P., Madelein D., Meyen S. 1988. Analysis of natural regeneration in a 200 years old beech stand. Silva Gandavensis 53: 61-81.

Nowacki G.J., Abrams M.D. 1997. Radial-growth averaging criteria for reconstructing disturbance histories from presettlement-origin oaks. Ecological Monographs 67: 225-249.

Petráš R., Pajtík J. 1991. Sústava česko-slovenských objemových tabuliek drevín, Lesnický Časopis 37: 49-56.

Pinheiro J., Bates D., DebRoy S., Sarkar D. and the R Development Core Team, 2013. nlme: Linear and Nonlinear Mixed Effects Models. R package version 3.1-108. URL http://cran.r-project.org/web/ packages/nlme/

Podrázský V., Remeš J. 2006. Changes in humus forms in gaps of the canopy of semi-natural beech stand. Journal of Forest Science 52: 243-248.

Podrázský V., Remeš J. 2007. Změny kvality a množství nadložního humusu při přirozeném zmlazení bukových porostů na území Śkolního lesního podniku Kostelec nad Černými lesy. Zprávy lesnického výzkumu 52: 118-122.

Průša E. 1985 Die böhmischen und mährischen Urwälder - ihre Struktur und Ökologie. Academia Verlag, Praha.

R Development Core Team, 2012. R: A Language and Environment for Statistical Computing. R Foun- dation for Statistical Computing, Vienna, Austria, ISBN3-900051-07-0. http://www.R-project.org.

Ritter E., Dalsgaard L., Einhorn K.S. 2005. Light, temperature and soil moisture regimes following gap formation in a semi-natural beech-dominated forest in Denmark. Forest Ecology and Management 206: 15-33.

Rozenbergar D., Mikac S., Anic I., Diaci J. 2007. Gap regeneration patterns in relationship to light heterogeneity in two old-growth beech-fir forest reserves in South East Europe. Forestry 80: 431443.

Stancioiu P.T., O’Hara K.L. 2006. Morphological plasticity of regeneration subject to different levels of canopy cover in mixed-species, multiaged forests of the Romanian Carpathians. Trees: Structure and function 20: 196-209.

Szwagrzyk J., Szewczyk J., Bodziarczyk J., 2001. Dynamics of seedling bank in beech forest: results of a 10-year study on germination, growth and survival. Forest Ecology and Management. 141: 237-250.

Topoliantz S., Ponge J.F. 2000. Influence of site conditions on the survival and growth of Fagus sylvatica seedlings in an old-growth beech forest. Journal of Vegetation Science 11: 369-374.

Vrška T., Hort L., Adam D., Odehnalová P., Horal D. 2001. Virgin forest reserves in the Czech Republic and their developmental dynamics. 1 - The Bohemian-Moravian Upland (Polom, Žákova hora). Academia, Praha.

Wagner S. 1999. Ökologische Untersuchungen zur Initialphase der Naturverjüngung in Eschen-Buchenmischbeständen. Schriften aus der Forstlichen Fakultät der Universität Göttingen und der Niedersächsischen Forstlichen Versuchsanstalt, BD. 129. J. D. Sauerländer's Verlag, Frankfurt.

Wagner S., Fischer H., Huth F. 2011. Canopy effects on vegetation caused by harvesting and regeneration treatments. European Journal of Forest Research 130: 17-40.

Yamaguchi D.K. 1991. A simple method for cross-dating increment cores from living trees. Canadian Journal of Forest Research 21: 414-416. 